International Journal of Instruction e-ISSN: 1308-1470 • www.e-iji.net

Article submission code: 20200813073553

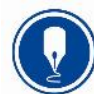

October $2021 \bullet$ Vol.14, No.4

p-ISSN: 1694-609X

pp. 391-410

Received: 13/08/2020

Revision: 18/03/2021
Accepted: 11/04/2021

OnlineFirst: 02/08/2021

\title{
Collaborative Writing Using Process Writing Approach: The Effect of Group Size and Personality Types
}

\section{Winarti}

Universitas Negeri Malang, East Java, Indonesia,winarti.wa@gmail.com

Bambang Yudi Cahyono

Prof., Universitas Negeri Malang, East Java, Indonesia, yudic2000@yahoo.com

\section{Nur Mukminatien}

Universitas Negeri Malang, East Java, Indonesia, nur.mukminatien.fs@um.ac.id

\section{Niamika El Khoiri}

Universitas Negeri Malang, East Java, Indonesia, niamika.el.fs@um.ac.id

\begin{abstract}
This study investigated the effect of group size and personality types in collaborative writing on students' writing ability. It employed a quasi-experimental design with non-randomized pre-test and post-test groups. Three classes consisting of 88 undergraduate students of Mathematics department at one of public universities in Malang, Indonesia participated in this study. The first class (30 students) was assigned to write explanation essays using process writing approach in pairs; the second class (28 students) completed the writing task using the same writing approach in groups of four students; the last class (30 students) wrote essays individually. The teaching to the students in the three classes lasted 10 meetings including pre-test and post-test. The students working in pairs and groups in particular were required to answer personality type questionnaire to determine their tendency of being extrovert or introvert students. One-way ANOVA and independent sample t-test were employed to compare the students' post test score. The results of study showed that students working in pairs and groups had better writing ability than those who worked individually. It also revealed that students working in pairs outperformed those working in groups. Finally, there were no significant difference in the writing ability between extrovert and introvert students who worked collaboratively, either in pairs or in groups.
\end{abstract}

Keywords: collaborative writing, pair work, group work, personality types, writing ability

\section{INTRODUCTION}

It is a common practice in communicative second or foreign language classroom to assign students to compose a text together with other students particularly in a classroom

Citation: Winarti., Cahyono, B. Y., Mukminatien, N., \& El Khoiri, N. (2021). Collaborative Writing Using Process Writing Approach: The Effect of Group Size and Personality Types. International Journal of Instruction, 14(4), 391-410. https://doi.org/10.29333/iji.2021.14423a 
with a big number of students. Working together to complete a writing task in one of stages or through the whole stage of writing process is well known as collaborative writing. The activity itself is assumed to provide students with considerable amount of benefit as they can share the knowledge and solve language related problem together. Thus, collaborative writing in a second/foreign language teaching and learning has received much attention from researchers to investigate the role of working together in performing a task on the development of language learning. The implementation of collaborative writing has gained theoretical and pedagogical supports due to its role to promote language learning. From a theoretical perspective, the use of collaborative writing is supported by two major theories of language learning: the social constructivist view of learning which was suggested by Vygotsky (1978), and the output hypothesis theory from Swain (1995).

Some studies noted the positive effect of collaborative writing on the quality of written text produced by students. Storch's study (2005) compared text produced by individuals and pairs. The results of the study revealed that the texts composed by pairs were shorter than those produced by individual students, but the texts were better in terms of accuracy and complexity. A similar study examined the performance of two groups of second language students who wrote argumentative essays in pair and individually (Wigglesworth \& Storch, 2009). The comparison showed that essays written by pairs had better accuracy compared to written individually. Another study compared the effectiveness of collaborative writing and individual writing involving 38 first year EFL students who had to compose paragraphs (Shehadeh, 2011). The study showed that working collaboratively had given positive effect on students' paragraphs in terms of content, organization, and grammar.

Despite the potential benefits associated with collaborative writing, collaborative activity involving students to complete a certain writing task requires some considerable factors to create effective collaborative learning. As the educators, we need to consider those factors in order to take the most favourable benefit from assigning students in collaborative writing. The factors which may influence the collaborative activity are language proficiency (Kim \& McDonough, 2008; Leeser, 2004; Shin et al., 2016; Susanti et al., 2020; Watanabe, 2008; Watanabe \& Swain, 2007), students social status/position (Stone \& Kidd, 2011), motives Chang, 2010; Dobao, 2012; Yu \& Lee, 2015), personality (Ellis, 2003; Nussbaum et al., 2004), and group size (Lasito \& Storch, 2013; Dobao, 2012). Some factors have been under examined by previous studies to prove the effectiveness of those factors in the collaborative writing. Other factors are still left in questions whether there is an effect of those factors on students' learning.

Two factors that may influence the effectiveness of collaborative writing and became the focus of this study were group size and personality types. Those factors are considered important to be investigated in this study given that writing teachers often assign students in collaborative activity either in pairs and groups. The number of students engaging in a collaborative writing task might possibly give a different effect on the result of language learning since it is believed that more heads is better than one. It 
means that having more students in collaborative writing is claimed to give more valuable input, provide corrective feedback, and solve linguistic problems. Furthermore, personality types are regarded as an important factor in determining students' behaviour which affects the learning process (Dörnyei \& Ryan, 2015). It is hypothesized that a certain social behaviour of an individual has an effect on students' engagement in collaborative writing. In addition, compared to other factors such as students proficiency, the studies which specifically compared the opportunities that group size and personality types during collaborative writing may offer for L2 learning are still limited. Therefore, in order to fill the gap in the literature, this study explored the comparative influence of group size and personality types during collaborative writing students' writing ability.

\section{Literature Review}

A very small number of studies have been examined to compare the effectiveness of working in pair work and group work and the findings are far from being conclusive. One study involving seven pairs and seven small groups (three students) was conducted to compare the student interaction and language output produced while performing an oral communicative task (Lasito \& Storch, 2013). The result of the study found that pairs generated more language than small groups and more language-related episodes (LREs). Another study attempted to investigate the effect of collaborative writing task which was completed in pairs, groups and individual works on three aspects of writing quality (accuracy, fluency, and complexity) of written text produced, as well as the language related episodes produced during collaborative activity (Dobao, 2012). The study claimed that small groups tended to be more conducive to language learning because they encouraged a greater focus on language and in small groups there were more knowledge sources to draw on such deliberations which were more likely to be resolved correctly.

However, the previous study (Lasito \& Storch, 2013) mainly focused on measuring the effect of number of participants during communicative oral task and did not examine which group size the students reaped the more benefit during collaborative writing task. Meanwhile, Dobao's study (2012) did not measure the effect of collaborative writing on individual writing ability. The quality of joint-text produced during collaborative writing and individual writing became the parameters for establishing the success of collaborative writing. However, there was no post-test to measure the students' writing ability as the result of collaborative writing. In fact, the essential purpose of collaborative writing is how this strategy prepares students to write individually without any help from others. Therefore, the present study aimed to investigate the writing quality produced by students after they completed collaborative writing to find out the effect of collaborative writing on individual writing ability.

Another factor which may influence the effectiveness of collaborative writing is personality types. There are many different definitions of personality which are articulated by practitioners in SLA and Psychology considering the diversity of psychological approaches aroused in the personality studies. However, individual differences, behavioural dimensions and traits have been the basic notions in the 
definition of personality. Hence, this study used the definition of personality from behaviouristic approach since it attempted to see the effect of students' behaviour in collaborative writing which may be influenced by personality preference on students' writing ability. Eysenck (1967, as cited in Abali, 2006) defined personality as the characteristics and qualities of a person which are seen as a whole and which differentiate him or her from other people. A more detail definition was postulated by (Richards \& Schmidt, 2002) that personality is defined as "those aspects of an individual's behaviour, attitude, belief, thoughts, actions, and feelings which are seen as typical and distinctive of that person and recognized as such by that person and others". From those definitions, it can be concluded that personality is person's character that influences what to do to other people or his/her environment and it differs from others.

In the literature, a number of personality models have been proposed to understand the individuals' behaviours and characteristics. Each of these models is based on a different personality theory and presents different personality traits. There are at least three models of personality types proposed by practitioners (Tlili et al., 2016). The first model is Myers Briggs personality type indicator which is derived from Carl Jung's theory. It adds Jung's theory with the other aspects of the way a person process the information s/he gathers. It categorizes personality and preference into four types, namely extraversion-introversion, sensing - intuition, thinking - feeling, judging, perceiving. The next model is the five-factor model. It is a hierarchical organization of personality traits in terms of five basic dimensions: openness to experience, conscientiousness, extraversion, agreeableness and neuroticism. The last model was proposed by Eysenck called Hans Eysenck's model. In Eysenck' model, the category of personality is based on the view that every person has differences in the cortical arousal which controls human behaviour. Three dimensions of personality, namely psychoticism, extraversion and neuroticism are found in Eysenck's model.

Among the various model of personality types, extroversion and introversion were being the focus of this study since these categories were assumed to influence students' preference to interact with other students or tend to prefer working individually. Extrovert and introvert have distinctive characteristics which are seen from behavioural patterns. Jung (1971) defined the term extrovert and introvert from how a person moves their energy toward external or internal world (Tlili et al., 2016). Those who are in extrovert preference tend to move their energy toward the external world of individuals and activities. They prefer to spend substantial amounts of time on interacting or engaging with other people. Thus, extroverts are more interested in the activities and things in the world around them than on their own lives. Introverts, on the contrary, move their energy toward their inner world of feelings and ideas. People who have this preference tend to prefer being alone and avoid the activities which involve many people. Eysenck (1967, as cited in Abali, 2006) proposed observational behaviour for both extrovert and introvert. Extroverts have some behavioural pattern tendencies such as sociable, outgoing, talkative, responsive, lively, carefree, and leadership. Meanwhile, quiet, unsociable, reserved, anxious are some behavioural patterns which introverts have. Extroverts and introverts have their unique characteristics which coexist in a person and it will influence how they will behave in a certain situation. 
Of the limited personality type research on language learning, some studies have attempted to examine the role of personality types on learning achievement. A study on the participation of extrovert and introvert students in asynchronous communicative activities revealed that introverts would prefer this medium of learning compared to their counterparts since they had much time to think the idea before they shared it to their friends (Ellis, 2003). Another study found that introvert students with a high level of anxiety might be afraid of how the other students would react to what they did during the discussion (Nussbaum et al., 2004). From these findings, it may be predicted that introvert students tended to avoid the engagement of group discussion.

However, other studies which investigated the effect of personality types on language learning have prompted contrary results. A study conducted by Ahour and Haradasht (2014) explored the comparative influence of practicing competitive and cooperative learning in the class to see how these learning strategies could affect the reading comprehension of extroverts and introverts. It revealed that the extrovert groups did not outperformed introvert group in reading achievement test in the cooperative situation. A similar finding also showed that personality traits demonstrated no significant effect on learners' writing progress (Hajimohammadi \& Mukundan, 2011). It is argued that introvert students, like their counterpart extrovert students, gain a benefit from working in a group which has cooperative principles as they have opportunities to share and develop their ideas with their friends (Jacobs, 2014)

While the previous studies provide insights into collaborative learning and personality type research, the results are still inconsistent and there is not any research considering the effect of number of participants and personality types on students writing ability. Therefore, this study tried to examine the following research questions: Is there any significant difference in the writing ability of:

(1) the students working collaboratively and those working individually?

(2) the students working in pairs and those working in groups?

(3) extroverts and introverts working in pairs? and

(4) extroverts and introverts working in groups?

\section{METHOD}

\section{Research Design}

This study investigated the effect of group size and personality types in collaborative writing on students' writing ability. Referring to the objectives of the study, experimental research was employed since it enabled the researcher to estimate the effect of experimental treatment (Ary et al., 2010). To be more specific, this study used a quasi-experimental with non-randomized pre-test and post-test groups This design was chosen since it was impossible to randomly assign subjects to either experimental and control group due to the university system. In such a case, it was necessary to use subjects of study who were already organized into classes (intact class). 
This study firstly examined the effect of different types of writing strategy i.e., collaborative writing and individual writing on students' writing ability. When the result showed significant gains in term of the mean for collaborative writing compared to individual working, the investigation proceeded to find out the best grouping technique between collaborative writing in pairs and in groups. The next purpose of this study was to know the effect of students' personality types on students' ability in writing as students working in pairs and groups were classified into extrovert and introvert. The study compared the mean of writing text score from extrovert students with those from introvert students working in pairs. The comparison between the mean of extrovert students working in groups and the mean of introverts was also executed to know the effect of personality types on the writing ability.

\section{Participants}

The target population of this study was EFL students who were taking English course as English for Specific Purposes (ESP). The accessible subject was the fourth semester students of Mathematics department at Universitas Islam Negeri (UIN) Maulana Malik Ibrahim Malang, Indonesia who were taking English 2 as the compulsory subject after completing the previous English courses. There were 110 students divided into 4 classes taking English 2 focusing mainly on improving their writing skills. Mathematics students who were taking English 2 course were chosen in this study because of some considerations. First, they were learning English which focused on improving their academic writing. Moreover, in this semester they were learning an explanation text and how to write an explanation essay as well. Furthermore, when they were taking the course, they had passed the previous courses called English 1 and Extensive English 1 whose objectives were to improve their skills in reading and speaking. The English was taught in integrated way as it had 3 credits in each course. Thus, they had similar background knowledge of materials and have the same learning experience.

As has been noted, 4 classes were available to conduct this study and the department placed them in those classes on the basis of students' preference regardless of their English proficiency. According to the result of Test of English Proficiency conducted by Language Center UIN Malang, their English proficiency was at pre-intermediate to intermediate level. Since it was impossible to select the students and put them into some classes randomly in this educational system, three classes out of four classes were chosen to be used as the subjects of this study. Three classes (A, B, and C) were chosen for the current study as the total number of students in those classes were almost balanced, while the number of students in class D was smaller than the other classes. The three classes got different treatment. Class A consisting of thirty students was assigned to perform a collaborative writing activity in pairs; twenty-eight students from class B were given the writing task to collaborate in groups of four students, and there were thirty students in class $\mathrm{C}$ engaging in individual activities. 


\section{Instruments}

To collect the data for this study, some research instruments were devised, namely writing test, questionnaire, and scoring rubric for assessing explanation essay produced by the students.

\section{Writing Test}

A writing test was administered to gather data concerning students' writing ability before and after conducting the treatment. It measured how well the student spontaneously wrote in English without access to revisions and/or editing tools by comparing students' performance of a specific writing task with the criteria stated in the scoring rubric. To get the appropriate writing test for the objective of the study, the researcher did some sequences of activities which comprised developing the blueprint, writing the prompt, validating the draft (the blueprint and the prompt), revising the draft, trying out, analyzing the result of the try-out, and assembling the final form.

Concerning the topics to be used, they had to be appropriate for educational level and interest of the students. To achieve this, the researcher sought a number of interesting topics from the drafts written previously by senior year students who were not taken as the research subjects. There were selected relevant 15 topics related to Mathematics field which were in readiness to be given to the students. 60 students were invited to participate in selecting the top 4 topics based on his/her preference when they wrote the essay. Google form program was utilized to reveal students' preference as it was easy to gather quick responses and provided automatic calculation which allowed the researcher to obtain the result quickly. After the questionnaire was distributed through the program, the result showed a list of topic selected by the students from the most favorite topics to the least ones. Then, the researcher chose top six topics to be used in the prompt; three topics were for pre-test and the other three were for post-test. The topics for pre-test were "How to Calculate Volume of Cube, "How to Present Data into Graph, "How to Calculate the Probability of an Event", and the topics used in post-test were "How to Convert Fractions to Percent", “ How to Obtain the Volume Formula of Tube”, How to Prove Pythagoras Theorem".

The instruction to do the test was developed in such a way that it had the main factors as following: it was simple and short enough so that the students did not waste their time trying to figure out what was called for; it enumerated the topic being written; it specified the length of the test produced by students; it specified the amount of time the students had to complete the writing; it told the students what would be valued in their writing

\section{Questionnaire}

The next instrument to collect the required data for this study regarding personality types was questionnaire. Numerous questionnaires were available to be used to measure the personality types with the high validity and reliability. However, most of them were used to measure more than one personality types such as measuring extraversion/ introversion, sensing/ intuition, thinking/ feeling, and judging/perceiving. As the 
objective of this study was to measure personality types of extroversion and introversion, an appropriate questionnaire should be adapted from the available ones to reach the objective of the study. Among those types of questionnaire, the questionnaire from Eysenck personality Inventory was selected under some considerations. First, the items on the questionnaire were developed based on the well-defined indicators proposed by Eysenck which were the same as the indicators used in this study. Second, it was mostly used by other studies which also investigated the effect of personality type on language learning (Cahyono \& Mutiaraningrum, 2016) so its validity and reliability had been substantiated in terms of both the content and its application.

The questionnaire developed by Eysenck comprised of 57 yes-no questions which inquired respondents' preference on extraversion, introversion, and neuroticism. For this study, not all items from Eysenck questionnaire were appropriate to be adopted since some items were intended to measure neuroticism. Out of 57 questions from Eysenck' questionnaire 22 questions were taken to be used in identifying students' personality types. The language of those selected questions was reformulated in order for the students to understand each question clearly and also to make it appropriate with the context and purpose of the study. In addition to the adapting and adopting procedure, 51 new questions were necessary to be added to obtain the most complete and accurate information possible which could not be gained from the Eysenck's questionnaire.

After the items of the questionnaire had been developed, the next step to do was the review by experts. The purpose of the review was to ensure items were appropriate with the intended purpose. An expert who had the expertise in Psychology was involved to review the questionnaire. The expert was one of senior lecturers in Psychology Department at UIN Maulana Malik Ibrahim Malang and she was also Dean of Psychology Department at UIN Maulana Malik Ibrahim Malang who had teaching experience more than fifteen years. The review process was conducted qualitatively in which the expert was asked to put her opinions about the instrument regarding the content and clarity based on an evaluation sheet in which several aspects of the questionnaire were formulated as her guidance to evaluate it. She was also requested to suggest any modifications and suggest any changes were necessary. Once the questionnaire had been reviewed by the independent expert it must have been ready for field testing. 120 participants from various departments in science and technology faculty at UIN Maliki Malang took part in the field testing. They were selected on the basis of their resembling background with the subject of the study. The field test examinees should be representative of the subjects of the study. It meant that they should be as similar to future test-takers as possible. Moreover, the examinees should also be motivated; that was, they should be attempting to do as well as possible when they responded to the items. The questionnaire consisted of 73 items and it took approximately 10 minutes to answer all the items of the questionnaire. Out of 120 questionnaires, 100 were selected to be included in data analysis as some questionnaires were not valid as the participants did not answer one or two questions

The collected data from the field testing was then analysed to measure the validity and reliability of the questionnaire. The reason for doing so was to enhance the technical 
quality of the instrument by pointing out options that were non-functional and that should be improved or eliminated. In the light of validity, Pearson Product Moment method was utilized by referring to the $r$ table of .195 as the minimum requirement of the item validity for 100 respondents $(\mathrm{N}-2)$. The result of the analysis showed that 46 items were valid as the observed value was greater than 0.195. Meanwhile, 27 items were not valid and were not used in the final questionnaire. Not all valid items were included in the final questionnaire, however 34 items were considered to be used for categorizing students' personality given that those items had high validity score. Cronbach's alfa was also employed to obtain the value of the reliability coefficient as it became the indicator whether the questionnaire was reliable or not. Based on the analysis, the obtained Cronbach's Alpha in the description of the statistical analysis was .0788. The obtained value was considered acceptable, and the questionnaire was proven to be reliable. The final questionnaire consisted of 34 questions which were selected based on the result of testing validity and reliability in the pilot study.

\section{Scoring Rubric}

The last instrument used in this study was a scoring guide to rate students' writing ability. An analytical scoring guide was employed in this study. It is a procedure of giving scores to the quality of writing based on several criteria separately rather than given a single score (Weigle, 2002). The analytical scoring technique was selected from a number of options available such as holistic and primary trait scoring since this scoring technique was the most appropriate one to be used in this study since the aim of this study was to measure students' ability in the explanation essay.

There were five components of writing that made up the quality of writing and each of them had different criteria to be fulfilled. The component of content required students to demonstrate thorough knowledge of the purpose of an explanation text and provided relevant information with the facts and details that answered the how questions. Organization focused on how students' ability to a) write the opening paragraph which had a clear statement introducing how something happen, b) write detailed and accurate explanation in sequence order with all elements included, and c) write a well-developed closing paragraph which restated the main idea, reiterated the critical points, and stated the significance or importance of the topic in an interesting and creative way. Language use dealt with the use of relatively complex structure, simple present tenses, subject and verb agreement. Then, vocabulary was concerned with the use of accurate word choice and word form to transmit the intended meaning. The last was mechanics which included spelling, punctuation, and capitalization

The scoring rubric was provided with different weight for each component given that some aspects were considered to be more important than the others. It was decided that content and organization were given the greatest weight, which was 6 , vocabulary and grammar were weighed 5, and mechanic was weighed 3 . In addition, it had four-point scale for each component ranging from 1 (poor), 2 (fair), 3 (good), and 4 (very good). 


\section{Procedures}

Since the data collection activity had to follow the existing condition on that institution in which the study was carried out, the teaching procedures were in line with the syllabus used in the institution. The lesson plan was the same for all classes. The three classes were taught by the same lecturer, one of the researchers, who followed the syllabus, lesson plans, and materials provided prior to the treatment. Following the syllabus, all writing tasks were at the essay level and consisted of mainly the explanation essay. All students in three classes accomplished 10 meetings including pre-test and post-test and each section lasted for 90 minutes. In the treatment, students were assigned to write two explanation essays using process writing approach. The students completed the task through some stages starting from prewriting, drafting, evaluating the draft, revising and editing, and publishing. The detailed description of treatment procedure is displayed in Table 1

Table 1

Treatment procedures in pairs, groups, and individuals using writing process approach

\begin{tabular}{|c|c|c|c|}
\hline Meeting & Stages & Pairs and Groups & Individuals \\
\hline 1 & & Pre-test & Pre-test \\
\hline \multirow[t]{2}{*}{2} & Pre-writing & $\begin{array}{l}\text { The lecturer provided the pairs and } \\
\text { groups with a pre-writing worksheet. } \\
\text { The pairs and groups generated and } \\
\text { organized the ideas }\end{array}$ & $\begin{array}{l}\text { The lecturer provided students with a } \\
\text { pre-writing worksheet. } \\
\text { The students generated and } \\
\text { organized the ideas individually }\end{array}$ \\
\hline & Drafting & $\begin{array}{l}\text { The pairs and groups wrote a draft } \\
\text { based on the outline in pre-writing } \\
\text { activity }\end{array}$ & $\begin{array}{l}\text { The students wrote a draft } \\
\text { individually based on the outline in } \\
\text { pre-writing activity }\end{array}$ \\
\hline 3 & $\begin{array}{l}\text { Giving } \\
\text { Feedback }\end{array}$ & $\begin{array}{l}\text { Each pair and group read the draft and } \\
\text { gave a response to ideas and } \\
\text { organization of the draft and language } \\
\text { use }\end{array}$ & $\begin{array}{l}\text { Each of the students reads his/her } \\
\text { friend's draft and gave a response to } \\
\text { ideas and organization of the draft } \\
\text { and language use }\end{array}$ \\
\hline 4 & $\begin{array}{l}\text { Revising and } \\
\text { editing }\end{array}$ & $\begin{array}{l}\text { The pairs and groups revised and } \\
\text { edited the draft based on the feedback } \\
\text { from other pair/group }\end{array}$ & $\begin{array}{l}\text { Each of the students revised and } \\
\text { edited the draft individually based } \\
\text { on the feedback from his/her friend }\end{array}$ \\
\hline \multirow{2}{*}{$\begin{array}{l}\text { Outside } \\
\text { the } \\
\text { classroom }\end{array}$} & $\begin{array}{l}\text { Teacher } \\
\text { feedback }\end{array}$ & $\begin{array}{l}\text { Pairs and groups consulted the second } \\
\text { draft with the lecturer }\end{array}$ & $\begin{array}{l}\text { The students consulted the second } \\
\text { draft with the lecturer }\end{array}$ \\
\hline & $\begin{array}{l}\text { Revising and } \\
\text { editing the } \\
\text { second draft }\end{array}$ & $\begin{array}{l}\text { The pairs and groups revised and } \\
\text { edited the draft based on the feedback } \\
\text { from the lecturer }\end{array}$ & $\begin{array}{l}\text { The students revised and edited the } \\
\text { draft based on the feedback from the } \\
\text { lecturer }\end{array}$ \\
\hline 5 & Publishing & $\begin{array}{l}\text { The pairs and groups published the } \\
\text { final draft using Power Point } \\
\text { Presentation (PPT). }\end{array}$ & $\begin{array}{l}\text { The students published the final } \\
\text { draft using Power Point Presentation } \\
\text { (PPT). }\end{array}$ \\
\hline 6.7 .8 & $\begin{array}{l}\text { Drafting, } \\
\text { giving } \\
\text { feedback, } \\
\text { revising and } \\
\text { editing }\end{array}$ & $\begin{array}{l}\text { Repeated activities from meetings } \\
2,3,4 \text { with a different topic }\end{array}$ & $\begin{array}{l}\text { Repeated activities from meetings } \\
2,3,4 \text { with a different topic }\end{array}$ \\
\hline 9 & Publishing & $\begin{array}{l}\text { The pairs and groups published their } \\
\text { work in the form of a poster } \\
\text { presentation }\end{array}$ & $\begin{array}{l}\text { The student published their work in } \\
\text { the form of a poster presentation }\end{array}$ \\
\hline 10 & & Post-test & Post-test \\
\hline
\end{tabular}




\section{Data Collection}

To obtain the data needed, there were some procedures to be taken. First, prior to the treatment procedure, a pre-test was administered to make sure that there was no significant difference among three groups with regard to students' writing ability. The students in each class had to write an explanation essay individually in the classroom as it was instructed in a writing prompt. The writing prompt demanded students to compose the explanation essay relevant to their context of the field in approximately 300-400 words. The students could select one of the assigned topics. The students were given 90 minutes to finish their essay. They might not use available tools to help them in completing the assigned writing task such as dictionary or smart phone.

The second data concerning the students' tendency to extroversion or introversion was gathered through distributing a personality type questionnaire to the subjects of the study. The questionnaire consisted of 34 items and it was answered in the classroom by the students working in pairs and groups. It took approximately 10 minutes to answer all the items of the questionnaire. The students selected either "Yes" or "No" option for each statement indicating their tendency. The students received 1 point for each "Yes" answer and 0 for each "No" answer. Some items were unfavorable statements and contained reserved score as they phrased in negatively words. So, for these items "No" answer was scored 1 and "Yes" answer was scored 0.The total points of each student were calculated considering the "yes" or "No" answer s/he has given. After that, students' responses on the questionnaire were tabulated and summed up to obtain the total points for total items for each student. The students were found to have the tendency to extroversion if they gained greater than or equal to 17 points while the students who obtained less than 17 points belonged to introvert. The results of personality type questionnaire revealed that in pair work 13 students were categorized into extrovert and 17 students belonged to introvert. While in groups the number of extrovert students was higher than introvert students. There were 17 extrovert students and 11 introvert students.

The data of students' personality types were then utilized to arrange the formation of students working in pairs and groups. The formation was based on three classifications, namely extrovert with extrovert, introvert with introvert, and extrovert with introvert. As the number of extrovert and introvert students was not same, the composition of students in pairs and groups was adjusted to match the imbalanced numbers of categories (See Table 2)

Table 2

Personality type-based student formation

\begin{tabular}{lll}
\hline Category & Total & Total \\
\hline Extrovert + Extrovert & 3 pairs & 2 groups \\
\hline Introvert + Introvert & 5 pairs & 4 groups \\
\hline Extrovert + Introvert & 7 pairs & 1 group \\
\hline
\end{tabular}

Another data was collected by conducting post-test. The post-test was administered on the same day and at the same time for three classes. The students received a writing test 
prompt that required them to write the explanation essay. They had to write at least 3 paragraphs containing introductory, body and concluding paragraph. 90 minutes was provided to finish the writing task. All groups in this study completed the writing posttest individually. The students submitted the essay immediately afterward they finished writing it.

The finished essays from pre-test and post-test then were given to two trained raters to be evaluated to measure their writing ability. During the process of scoring, each student paper was scored anonymously by giving a code number to take away any biases. Since two raters were involved in evaluating the students writing, the training of the raters had to be done prior to maximize the accuracy of score and minimize the differences as a result of different background of raters. The obtained reliability coefficient $r$ from two raters was .885 . In evaluating them, the raters employed an analytical scoring rubric which measured 5 aspects of writing, namely organization, content, grammar, vocabulary, and mechanics. The final score used as the score of students' writing was the average of the two raters' scores.

\section{Data Analysis}

As there were 4 problems proposed in this study, the technique of data analysis was adjusted to the numbers of research problems. In the light of answering the research questions, the data from students' writing were tabulated in table and analyzed using descriptive and inferential statistics. Independent sample t-test and one-way ANOVA were employed as all of the assumptions were fulfilled for the calculation at the .05 significance level. The computation of both descriptive and inferential statistics was accomplished by using SPPSS version 20

\section{FINDINGS}

The results of descriptive statistics analysis of students' writing essay gained by the three groups in the pre-test are displayed in Table 3.

Table 3

Descriptive statistics on students' writing essay in pre-test

\begin{tabular}{llll}
\hline Treatment & $\mathrm{N}$ & Mean & SD \\
\hline Pair Work & 30 & 65.700 & 13.4014 \\
\hline Group Work & 28 & 62.214 & 14.3149 \\
\hline Individual Work & 30 & 60.283 & 17.0949 \\
\hline
\end{tabular}

As Table 3 indicates, the students working collaboratively in pairs achieved the highest mean (65.7 points) followed those working in groups (62.214 points) and those working individually respectively (60.283 points). The means for the three groups appeared to have no significant difference; however, to prove whether or not the three groups were homogenous, an ANOVA test was conducted and the result of the test is displayed in Table 4. 
Table 4

The result of statistical analysis using One-Way ANOVA (Pretest)

\begin{tabular}{llllll}
\hline & Sum of Squares & df & Mean Square & F & Sig. \\
\hline Between Groups & 451.641 & 2 & 225.821 & .999 & .373 \\
\hline Within Groups & 19215.856 & 85 & 226.069 & & \\
\cline { 1 - 3 } & & & & & \\
\hline
\end{tabular}

Table 4 demonstrates that there was no significant difference in the means among the three groups as indicated by the $p$ value which was higher than the .05 level of significance $(.373>.05)$. Thus, the three groups were homogenous in terms of their writing ability before the treatment was conducted.

The data obtained from posttest were analyzed to answer the first and second research questions and Table 5 displays the result of descriptive statistics

Table 5

Descriptive statistics on students' writing essay in post-test

\begin{tabular}{llll}
\hline Treatment & $\mathrm{N}$ & $\mathrm{Mean}$ & $\mathrm{SD}$ \\
\hline Pair Work & 30 & 77.467 & 10.3424 \\
\hline Group Work & 28 & 66.750 & 13.2717 \\
\hline Individual Work & 30 & 60.787 & 19.1321 \\
\hline
\end{tabular}

As can be seen from Table 5, the mean for each group had different value statistically. The mean obtained by pairs was 77.467 ; whereas the mean of group work was 66.750 , and individual work had mean of 60.787. It is important to note that the highest mean was achieved by the students assigned the writing task collaboratively in pairs and the students working in individuals had the lowest mean. In addition, the results of mean indicated that the students who completed the writing task during collaborative writing either in pairs or groups demonstrated better ability in writing than the students working individually. However, further statistical analysis using one-way ANOVA was needed to determine whether the difference among the means of the three groups was significantly meaningful (See Table 6)

Table 6

The results of statistical analysis using One-Way ANOVA

\begin{tabular}{llllll}
\hline & Sum of Squares & df & Mean Square & F & Sig. \\
\hline Between Groups & 4281.172 & 2 & 2140.586 & & \\
\hline Within Groups & 12471.711 & 85 & 146.726 & & \\
\hline Total & 16752.883 & 87 & & & \\
\hline
\end{tabular}

Table 6 shows that the $p$ value resulted from the statistical analysis was .000 which was less than 0.05 . It means that there was a significant difference among the effect of three learning modes on all the participants. It can be concluded that the students performing writing task collaboratively had better writing ability than those assigning the writing task individually. 
Then, to reveal whether the students working in pair or working in groups had significant differences in their writing ability, the independent sample t-test was administered with the Alpha value .05 as the significance level. The Table 7 displays the result of data analysis.

Table 7

The result of independent sample t-test of means of post-test in pairs and groups

\begin{tabular}{llllllll}
\hline & $\mathrm{N}$ & Min & Max & Mean & SD & Sig. (2-tailed) \\
\cline { 1 - 5 } Pairs & 30 & 57.5 & 97.0 & 77.467 & 10.3424 & .01 \\
\hline Groups & 28 & 32.5 & 89.0 & 66.750 & 13.2717 & \\
\hline
\end{tabular}

The result of post-test revealed that the students working in pairs during collaborative writing had a significantly better writing ability than those working in groups. It is evident in the results of both descriptive and inferential statistics. The descriptive statistics showed that the mean of the students who performed collaborative writing in pairs was higher than the mean of the students working in groups and the mean difference between the two groups was 10.717 points. Furthermore, the result of inferential statistics indicated more convincing evidence as the means gained from the two groups were significantly different. By having the significance level of .05 , the statistical analysis reported that the $p$ value was .01 which was lower than the level of significance .05 meaning that the students working in pairs significantly had better writing ability than those working in groups after being given collaborative writing using process writing.

With respect to the third and fourth question, effects of personality types on students' writing ability, results of the statistical analysis displayed in Table 8 and 9 show that personality types did not have a significant effect on students' writing ability during collaborative writing

Table 8

Comparison of means of the extrovert and introvert students working in pairs

\begin{tabular}{lllllll}
\hline & $\mathrm{N}$ & Min & Max & Mean & SD & Sig. (2-tailed) \\
\hline Pair-Extrovert & 13 & 57.5 & 87.0 & 73.731 & 9.7609 & 0.83 \\
\cline { 1 - 6 } Pair-Introvert & 17 & 60.5 & 97.0 & 80.324 & 10.1195 & \\
\hline
\end{tabular}

Table 8 shows that the introvert students appeared to have better writing ability than the extrovert students as descriptive statistics indicated that the mean of the introvert students was higher than that of the extrovert students. However, the $p$ value obtained from inferential analysis was greater than the level of significance (.083>.05). It means that the difference between the two means was not significant. Therefore, it is concluded that the difference of personality types students had did not make the distinctive students' ability in writing the explanation essay.

Table 9

Comparison of means of the extrovert and introvert students working in groups

\begin{tabular}{lllllll}
\hline & $\mathrm{N}$ & Min & Max & Mean & SD & Sig. (2-tailed) \\
\hline Group -Extrovert & 17 & 32.5 & 87 & 64.882 & 13.92 & 0.364 \\
\cline { 1 - 6 } Group -Introvert & 11 & 52.0 & 89 & 69.636 & 12.26 & \\
\hline
\end{tabular}


Table 9 shows that the mean for the introvert students who completed collaborative writing in groups was higher than the mean for the extrovert students. However, since the $p$ value obtained from the t-test (.364) was greater than the 0.5 level of significance, the writing ability of the introvert students was not significantly different from the writing ability of the extrovert students.

\section{DISCUSSION}

The result of the study comparing collaborative and individual writing supports the preceding theories and studies which asserted that working together in composing a draft is believed to be beneficial for students in the process of learning a second or foreign language (Dobao, 2012; Mirzaei \& Eslami, 2015; Nassaji \& Tian, 2010; Shehadeh, 2011; Storch, 2005; Storch \& Wigglesworth, 2007). From sociocultural perspective, students' cognitive development including knowledge and skill of English are initially expanded through having interaction with other students in this case with the more capable students. Students should be provided the pedagogical activities which encourage them to work together and complete the activities collaboratively. Such as those activities involving collaborative working are believed to be more effective in improving students' skill as the students produce the language to not only convey the meaning but also developing meaning. The collaborative tasks also facilitate students to internalize and consolidate the language knowledge students get during the process of interaction with other students (Swain \& Lapkin, 2001). Seen from Zone of Proximal Development (ZPD), students work together with other students who have different ability and the capable students can help the less capable ones, so this such environment is proved to be a supportive environment to help students enhance students' language skill (Mirzaei \& Eslami, 2015)

The effectiveness of collaborative writing compared to individual writing in this study is likely due to some factors. Compared to individual writing, collaborative writing has some characteristics which are remarkably beneficial to facilitate students in completing the assigned task. The most prominent feature of collaborative writing is reciprocal interaction between or among the students (Fung, 2010). During the interaction, each student has ample opportunity to engage in the writing activity which encourages students to share ideas, help each other, solve related language problem, and others. The second factor that may play an important role in collaborative writing in this study is that the writing task the students completed involves a writing process in which some stages are required to be done by the students. In collaborative writing, along with the process writing, the students participate in interaction throughout the entire writing process whether it is pre-writing, writing a draft, or reviewing the draft.

With the regard to the second question, the result showed that students working in pairs had better ability compared to students working in groups. It is surprising as it was expected that the students working in group of four outperformed the students working in pairs as the groups were assumed to have more diverse knowledge resources to be pulled out during completion of the task. The previous study investigating the number of students in the collaborative writing also reported that students in group had better writing quality in terms of text accuracy (Dobao, 2012). It also revealed that students in 
group work were likely to have ability to find the correct solution when they had language related problems since they shared more linguistic resources and it had a positive impact on the quality of the text written by students.

Some factors may involve in contributing to the significant positive effect of collaborative writing done in pairs compared to group work. The students in pair work have more opportunities to involve themselves on the task. The greater opportunity in pair is the result of the number of students in pair work which consists of only two students compared with the group work which has four students. Other studies have attempted to investigate what actually happened when students were assigned to complete the task in pairs and groups. Foster's study (1998) found that students in pair work produced more language than those in small group and students working in pairs contributed their knowledge to the task evenly. This study also found that many students working in small group were silent and not giving contribution on the tasks. Similar result was from Lasito and Storch (2013) who found that pair work produced more Language Related Episodes (LREs) whereas group work generated very few numbers of LREs. The production of LREs during collaborative activity is believed to mediate the construction of linguistic knowledge and it may have an effect on the ability of students' ability in writing after the treatment.

Another factor that may influence the superiority of pair work in this study is dealing with conflicts arising during the collaborative writing. It seems that group work which has more participants has great possibility to have conflict among the members. Although they had known each other very well while the present study conducted was the second year for them, they definitely came to the class by bringing various social, affective, cognitive factors. These differences could create challenges and it could be detrimental the effectiveness of collaborative writing (Näykki et al., 2014). In pair work, however, the conflict between students could be reduced since it only consists of two members and they tend to solve the conflict easily.

The findings of this study also confirm the previous studies conducted to investigate the effect of personality types on language learning showing that both extrovert and introvert could be successful learners. The previous study reported that students' progress in writing after assigning self-correction was not influenced by personality types and students gained benefits of self-correction regardless of the personality type they had (Hajimohammadi \& Mukundan, 2011). The results of this study are supported by the findings of another study which revealed that there was no significant statistical difference between extrovert and introvert students seen from their proficiency in writing (Cahyono \& Mutiaraningrum, 2016). All in all, these studies counter the negative stereotypes of introvert which stated that introverts were inferior to extroverts in learning second/foreign language. In fact, both extrovert and introvert students have the same opportunity to learn the language.

Some factors might influence students' engagement during collaborative writing. one factor dealt with students' writing proficiency. The result of Leeser's investigation (2004) showed that low proficiency students would not obtain the benefit of some collaborative tasks when they worked with the same level. Kormos (2012) in her review 
of literature presented that students' differences including cognitive factor played greatly essential in L2 writing process which involved the planning, formulation, transcribing, and editing phases of writing. Although her review was based mainly on individual writing in which students did writing activity individually, she believed that this factor, along with motivational factors, could affect how students worked to compose jointly written text collaboratively.

The next factor that could influence the success of collaborative writing is students' motive to engage in the activity. Student's motives are grounded on activity theory perspective proposed by Leont'ev (1978 \& 1981 as cited in Yu \& Lee, 2014). This theory holds that all human activities are geared consciously by motives and are realized by goal-oriented action. It provides an explanation concerning why some students are very active to engage in the activity while others have reverse action during collaborative activity and it is due to each member has different motive as to whether they have willingness to take part on the activity. A study conducted by $\mathrm{Yu}$ and Lee (2014) confirmed this factor revealing that the students' active engagement in peer feedback activity could be governed by their motives. From this finding, students who had distinct motives would take different attitude and performed collaborative activity in different ways.

\section{CONCLUSION}

This study has revealed that collaborative writing either it is done in pairs or groups is more effective than writing alone. From sociocultural perspective, working together in solving language-related problems during the completion of the task serves mutual assistance which enables the students to develop the linguistic knowledge. In addition, this study has shown that the group size has a role in affecting students' ability in writing, suggesting that pair work is more preferable when assigning students in collaborative writing using process writing. Finally, from this study it can be concluded that both types of personality have the same chance to work collaboratively either in pairs or groups.

The findings of this study add further empirical evidence of the benefit of collaborative writing in the foreign language learning context. It means that the writing teachers are suggested to incorporate collaborative writing as pedagogical tool to improve students' writing ability and create conducive social atmosphere of learning English. Writing is not only a solitary activity; therefore, teachers can assign students to work collaboratively with other students. However, teachers need to consider the number of students involved in the assigned task because group size influences the success of collaborative learning. It is also important to note that both extrovert and introvert students have the same chance to be successful especially during collaborative learning. In light of the present study, future researchers may involve larger number of participants with different proficiency levels to see the effectiveness of group size during collaborative writing on students' writing ability. Future researchers can also investigate the interaction between the collaborative writing and factors other than personality types such as the type of paragraph writing which might influence the effectiveness of collaborative writing. 


\section{REFERENCES}

Abali, F. (2006). The effect of personality traits extroversion/ introversion on verbal and interactive behaviors of learners, Retrieved 02 Feb, 2019 from http://www.thesis.bilkent.edu.tr/0003221.pdf.

Ahour, T., \& Haradasht, P. N. (2014). The comparative effect of using competitive and cooperative learning on the reading comprehension of introvert and extrovert EFL learners. Advances in Language and Literary Studies, 5(4), 206-215

Ary, D., Jacobs, L. C., Razavieh, A., \& Sorensen, C. K. (2010). Introduction to research in education. Belmont, CA: Thomson/Wadsworth.

Cahyono, B. Y. \& Mutiaringrum, I. (2016). Indonesian EFL students' proficiency in writing and ability in speaking across personality learning styles. Studies in English Language Teaching, 4(2), 168-186

Chang, L. Y. H. (2010). Group processes and EFL learners' motivation: A study of group dynamics in EFL classrooms. TESOL Quarterly, 44(1), 129-154.

Dobao, A. F. (2012). Collaborative dialogue in learner-learner and learner-native speaker interaction. Applied Linguistics, 33(3), 229-256.

Dobao, A. F (2012). Collaborative writing tasks in the L2 classroom: Comparing group, pair, and individual work. Journal of Second Language Writing, 21(1), 40-58.

Dörnyei, Z., \& Ryan, S. (2015). The Psychology of the language learner revisited. New York: Routledge.

Ellis, A. (2003). Personality type and participation in networked learning environments. Educational Media International, 40(1-2), 101-114.

Foster, P. (1998). A classroom perspective on the negotiation of meaning. Applied Linguistics, 19(1), 1-23.

Fung, Y. M. (2010). Collaborative writing features. RELC Journal, 4l(1), 18-30.

Hajimohammadi, R., \& Mukundan, J. (2011). Impact of self-correction on extrovert and introvert students in EFL writing progress. English Language Teaching, 4(2), 161-168

Jacobs, G. (2014). Introverts can succeed with. Parole, 4(1), 83-93

Kim, Y. J., \& McDonough, K. (2008). The effect of interlocutor proficiency on the collaborative dialogue between Korean as a second language learners. Language Teaching Research, 12(2), 211-234

Kormos, J. (2012). The role of individual differences in L2 writing. Journal of Second Language Writing, 21, 390-403

Lasito, \& Storch, N. (2013). Comparing pair and small group interactions on oral tasks. RELC Journal, 44(3), 361-375 
Leeser, M. J. (2004). Learner proficiency and focus on form during collaborative dialogue. Language Teaching Research, 8(1), 55-81

Mirzaei, A., \& Eslami, Z. R. (2015). ZPD-activated languaging and collaborative L2 writing. Educational Psychology, 35(1), 5-25

Nassaji, H., \& Tian, J. (2010). Collaborative and individual output tasks and their effects on learning English phrasal verbs. Language Teaching Research, 14(4), 397419

Näykki, P., Järvelä, S., Kirschner, P. A., \& Järvenoja, H. (2014). Socio-emotional conflict in collaborative learning-A process-oriented case study in a higher education context. International Journal of Educational Research, 68, 1-14

Nussbaum, E. M., Hartley, K., Sinatra, G. M., Reynolds, R. E., \& Bendixen, L. D. (2004). Personality interactions and scaffolding in on-line discussions. Journal of Educational Computing Research, 30(1-2), 113-137

Richards, J. C., \& Schmidt, R. (2002). Longman dictionary of language teaching and applied linguistics. London: Pearson Education Limited.

Shehadeh, A. (2011). Effects and student perceptions of collaborative writing in L2. Journal of Second Language Writing, 20(4), 286-305

Shin, S. Y., Lidster, R., Sabraw, S., \& Yeager, R. (2016). The effects of L2 proficiency differences in pairs on idea units in a collaborative text reconstruction task. Language Teaching Research, 20(3), 366-386

Stone, P., \& Kidd, A. (2011). Students' social positioning in the language classroom: Implications for interaction. RELC Journal, 42(3), 325-343

Storch, N. (2005). Collaborative writing: Product, process and students' reflections. Journal of Second Language Writing, 14(3), 153-173

Storch, N., \& Wigglesworth, G. (2007). Writing tasks: The effects of collaboration. In M. Garcia Mayo (Ed.), Investigating tasks in formal language learning (pp157-177).

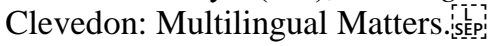

Susanti, A., Widiati, U., \& Cahyono, B. Y. (2020). The effect of proficiency pairings on EFL students' writing ability in genre-based approach context. International Journal of Evaluation and Research in Education, 9(1), 245-251

Swain, M. (1995). Three functions of output in second language learning. In B. Seidlhofer (Ed.), Principle and Practice in Applied Linguistics: Studies in Honor of H.G. Widdowson (pp125-144). Oxford: Oxford University Press.

Swain, M., \& Lapkin, S. (2001). Focus on form through collaborative dialogue: Exploring task effects. In M. Bygate, P. Skehan, \& M. Swain (Eds.), Researching pedagogic tasks: Second language learning, teaching and testing (pp. 99-118). London: Longman. 
Tlili, A., Essalmi, F., Jemni, M., Kinshuk, \& Chen, N. S. (2016). Role of personality in computer based learning. Computers in Human Behavior, 64, 805-813

Vygotsky, L. S. (1978). Mind in society: The development of higher psychological processes. Cambridge, MA: Harvard University Press.

Watanabe, Y. (2008). Peer-peer interaction between L2 learners of different proficiency levels: Their interactions and reflections. Canadian Modern Language Review, 64(4), $605-635$.

Watanabe, Y., \& Swain, M. (2007). Effects of proficiency differences and patterns of pair interaction on second language learning: Collaborative dialogue between adult ESL learners. Language Teaching Research, 11(2), 121-142.

Weigle, S. C. (2002). Assesing writing. Cambridge: Cambridge University Press.

Wigglesworth, G., \& Storch, N. (2009). Pair versus individual writing: Effects on fluency, complexity and accuracy. Language Testing, 26(3), 445-466

Yu, S., \& Lee, I. (2015). Understanding EFL students' participation in group peer feedback of L2 writing: A case study from an activity theory perspective. Language Teaching Research, 19(5), 572-593. 